\title{
Discussing political crisis as a social phenomenon: a short critical look
}

\section{Discutindo a crise política como um fenômeno social: um breve olhar crítico}

Carlos Potiara Castro - Doutor em Ciências Sociais, pela Universidade de Campinas (UNICAMP). Professor da Universidade de Brasília (UnB).E-mail: carlospotiara@unb.br

\begin{abstract}
This paper seeks to interpret political and institutional crisis from a perspective that prefers to interpret its internal dynamics, as a method to explicit the whole social process. It suggests that to interpret political crisis, it is necessary to make longer observation of the moves and actions of the main players and institutions in operation, in a context of social complexity. Thus, this paper aims to explicit the inability to focus on the outcomes of a political crisis, without taking into account its internal processes, which vary according to the diffuse and specific political capital possessed by social and institutional players. Thereby, political crisis are moments of fluidity of the prior political equilibrium, which can be amended on new bases, with a new legitimacy brought by individual and institutional performance in specific social space and historical time.
\end{abstract}

\section{Keywords}

Political crisis. Institutional crisis. Chaos and complexity. Diffuse and specific capital. Institutional legitimacy. Political system.

\section{Resumo}

Este trabalho busca interpretar as situações de crise política a partir de uma perspectiva que compreende que as dinâmicas internas a esses processos institucionais são especialmente significativas e explicativas do todo. $\mathrm{O}$ artigo sugere que uma interpretação mais acurada das crises políticas é necessariamente devedora de uma observação mais demorada das jogadas, ações e movimentações dos principais atores sociais e das instituições, em um contexto de complexidade social. Busca-se explicitar a insuficiência do foco no princípio e nos resultados das crises políticas, sem levar em consideração os processos internos, que variam de acordo com os capitais difuso e específico detidos pelos principais atores individuais $\mathrm{e}$ institucionais. Desse modo, as crises podem ser vistas como momentos de fluidez do equilíbrio político, que se refaz em novas bases, sustentadas na aquisição de uma nova legitimidade a partir do desempenho e das jogadas dos agentes em operação naquele espaço e tempo específicos.

\section{Palavras-chave}

Crise política. Crise institucional. Capital difuso e específico. Legitimidade social. Sistema político. 


\section{INTRODUCTION}

The subject of this paper has been selected because it deals with one of the most important questions in political sociology. Social and institutional crises are generally periods of upheaval and fast change of morals, behavior and of the institutions themselves, therefore with enormous political potential. However, crises have their own logic of operation and their outcomes are all the more dubious. The challenges posed to social scientists are proportional to this uncertainty.

We will discuss more often about two major schools with their different approaches and methodologies. The first one brings out the possibility of forecasting crisis situations from studying economic statistics and the living standards of a given society. The second one has a different view that social and political crisis surge in agreement with a historical and institutional linearity which causes - for its reproduction as for its renewal - critical situations generating a social force larger than the one of its inertia. However, the main idea of this paper is that crisis situations are normal components of the political life of our societies.

Understanding mobilizations as natural is necessary to explain a certain number of specific situations. For example, the military coup d'état of March 1964 in Brazil, occurred mainly due to President João Goulart's political agenda who intended, during a certain period of time, to gain support to his government from the popular forces, (DRAKE, 1966) by making concessions to them. The coup d'état annulled this agenda, replacing its main points with others. The rising popular mobilization, mainly in the poor Northeast, was suffocated and its development halted. Today, after a redemocratization phase, it is verified that some points of this agenda tend to reappear on the Brazilian political scene. Therefore, social movements such as those of the landless workers, MST, acquired an important political force and placed, once more, in the national public scene the issue of agrarian reform, in an extremely unequal country from an economic and social point of view. The dysfuntionallity in these decisions are evident, but only from the point of view of the most affluent economic classes, not in the action to counter social reforms in itself. And apparently, this kind of specific situation will exist as long as the inequality belongs and that the gap between classes is not supported by a strong institutional force (such as the military). 
In this paper, I will initially try to show mobilizations as a continuity process and a political movement with an important tactical presence, even if it is an unconventional political process. Furthermore, we will try to explain why we cannot understand political resources as something that can be transferred from a political group or institution to another one. This shows that social and political mobilizations have their own logic. And, that an economic methodological system is not the best framework to analyze social crisis situations.

After that, I will propose the perspective that, what makes the specific character of our modern societies is their chaotic way of organization. What follows from this argumentation is important to the extent that we cannot talk about a pure institutional logic. Next, we will talk about another important characteristic of social and political crisis - the process of loss of legitimacy of political leaders, public institutions and social organizations. To a large extent, the process of loss of legitimacy retains responsibility for the birth of political crisis situations. We can refer to some sort of breaking an implicit contract between the politicians and the other participating members of the political system. Finally, paradoxically, I will propose that one possible settling for a social crisis circumstance continues to be the institutional one. What denotes that there may be a transfer of the crisis to a legitimate and conventional political sphere. However, even here, it's difficult to predict the final outcome.

\section{THE DYNAMICS OF POLITICAL AND SOCIAL MOBILIZATION}

To start this section, we will underline the perspective pointed out by the French author Michel Dobry. In his book (DOBRY, 1992), he argues that we have to restore the internal dynamics of the social and political mobilizations which affect simultaneously several societal spheres to better understand political crises phenomena. To do so, he makes some personal choices about the perspective he adopts.

The first of such choices is the one of continuity. It means that the springs of political crises are not the effect, as it might be described by neo-positivists and "organic" sociology theories, of individuals or collective pathological operations. Dobry will point out to the importance of returning to social and political crisis situations its normality status. 
This hypothesis also corresponds to a displacement of the theoretical interest towards events in the processes of political crisis itself to the detriment of the political result from its development. Michel Dobry remarks that in general "analysts of Revolutions love origins and outcomes, but often neglect organization and dynamics and even sometimes agency" (McADAM; TARROW; TILLY, 1997, p. 143). In methodical terms, such argument makes reference to the fact that one cannot make an analysis of political crisis starting from their results. These results do not represent what occurs inside societal movements, and do not restore the logic or the tactics of the players and their leaders and representatives. This is an approach that adopts, to some extent, a Clausewitz's tactical point of view, but without the perspective of continuity as "means-ends".

Mainstream Political Science in the 1960s in the field of political crisis would consider that the idea of mobilization has only a few connections with the social player's tactical activity. Even if "the starting point for the study of contentious politics were the Western social movement cycle of the sixties" (McADAM; TARROW; TILLY, 1997) ${ }^{1}$. Thus, the concept of mobilization makes sense only as a modernization or a "general process of change" (DEUTSCH, $1961)^{2}$ of a traditional society towards a modern way of life. For Dobry, the central characteristic of these empirical data is that fact that it alienated from the mobilization and tactics operated by the main social players questioning institutional public processes.

It was Amitai Etzioni who first cut off the umbilical relation between mobilization and modernization of current societies (CHAZEL, 1975). He gave a new definition for mobilization, simply saying that this phenomenon is a process by which a social unit acquires important control of assets (ETZIONI, 1968 apud CHAZEL, 1975), which does not necessarily mean modernization of a society. Thus, we can make reference to social mobilizations aiming to paralyze a modernization process. Or, it can be counter-revolutionary and distant from an

1 We will also find in this article a description (p. 145-151) of the three methodological approaches that was adopted by researchers in the sixties: the structural one - with a marked difference between the American scholars "like Charles Tilly (1975) and Sidney Tarrow (1983, 1989)" that "saw collective action gravitating around the political struggle". Followed by Western Europeans authors, with a different kind of structuralism, a post-Marxist one (p. 145) - adopting a rationalist approach - based particularly on the "version of the collective action theory brought by the American economist Mancur Olson" (p. 147) - and the cultural one primarily from Marxist perspective, in the work of authors like Gramsci, Foucault, Derrida (p. 149) and Lukács.

2 This author considers social mobilizations as specific political effects such as: topic pressures to increase governmental capacities; strengthened political participation; or transformation of the flow of political communication. 
intention for modernization. Apparently, Etzioni aims to concentrate his analysis on the player's action. However, he still understands mobilization as social change. Nonetheless, for him, it is necessary to concede that it is true that those two variables- modernization and mobilization come together rather frequently.

Another point to be emphasized is the definition of the notion of "mobilization". In practical terms, it can be understood as a "move" in a social conflict context (DOBRY, 1992, p. 21). From this perspective, it also implies that social mobilization could be interpreted as a concrete action in the political sphere. Based on this viewpoint of mobilization as a political advance, we can conceive it as the individual or collective behavior that will have the propriety to affect the expectations of the protagonists of a given conflict about the performance of the other players (GOFFMAN, 1968) ${ }^{3}$. Therefore, using the social media to coordinate demonstrations, to erect barricades in Cartier Latin, to occupy public buildings, to dissolve the government (in a Parliamentary regime), to announce a candidacy prior to elections constitute political "moves" (DOBRY, 1983). Reminding that, these activities may only have a symbolic value. For example, the countrywide internet blackout implemented by the Egyptian government days before the fall of Mubarak was perfectly seen by the movement protagonists as a menace, and it had probably changed their own political calculations. It also sparked the use of Facebook pages (CASTELLS, 2015; WEYLAND, 2012; NOGUEIRA; CASTRO, 2014). Or, decades ago, the meeting between President De Gaulle and military officers in Baden-Baden in May 1968 was understood as the effective use of French troops in the conflict fomented by the student movement.

\section{POLITICAL MOBILIZATIONS: TWO CONFLICTING PERSPECTIVES}

By arguing that mobilizations are instrumental, it may be inferred that (moves) in social crisis situations have an evident and tangible objective. The resources being mobilized are regarded as complex and elementary means to be used by political players concerning the achievement of specific ends. The effect of this instrumental vision consists in considering mobilized resources as entities isolated from the social context in which they exist and operate, as if

\footnotetext{
To better understand the relationship between social players and their environment, see the concept of "existential situation". For example, in Goffman (1968).
} 
they were "independent things". The characteristics of the mobilized resources are implicit to the instrumental point of view as something independent from social relations.

Some political scientists even say that there's an "intrinsic nature" of the mobilized resources. It is true that weapons and currency have a stable physical propriety. Therefore, the instrumental perspective understands that political resources could be exchanged, operating like economic goods and markets. Political resources would be an attributed value, resulting from a supply and demand scheme.

However, one cannot say the same when referring to legitimacy and charisma. Accordingly, an argument against an instrumental vision of mobilization is based on the fact that political resources have stable proprieties in very specific social logic (DOBRY, 1992). Thus, these resources cannot be transferred from a social group to another, and neither can produce the same effect in two diverse situations. Thereby, the electoral success of a party is not easily transmitted to another one. Or, the percentage of the votes obtained in a Municipal election does not necessarily end up in the same result for the Legislative houses. It is challenging, for example, for the British Communist Party to convert in votes and in political mobilization its influence in the Labor Unions. Therefore, this instrumental vision leads to an erroneous design in economic terms, distant from what really confers the "value" of mobilized resources. In regards to the social relations, there is no parallel to currency for market exchanges.

In this perspective, social and political crises are mobilizations and moments of transformation in the social system leading to a critical state.

\section{TRANSFORMATION OF THE POLITICAL SPHERE}

Therefore, neither the value, nor the effectiveness of political resources transfer their properties nor the social players' calculations can be apprehended independently to the complex network within mobilizations are contextualized. In this regard, and in reference to political crises, the point of view of Michel Dobry is correct when he stresses the opposition between routine situations and critical ones. Thus, the perspective raised here is based on the assumption that political crises are social mobilizations, that leads to transformation of prior state - a passage of social systems. 
Nevertheless, this complex process needs to be considered carefully. In this aspect, the structural characteristics of multi-sector mobilizations involve shared internal processes among representatives of internal processes and with those which relate to the external aspects of such movements. Namely, internal aspects correspond to specific social logic and its external face to the autonomy that a given sector has concerning the myriad of other ones (DOBRY, 1992).

In this regard, a long-lasting theoretical tradition has already identified, and described a "specific institutional logic" forged from standard ideals. For example, the market logic, the internal operation of rational bureaucracies, the Military system (as disciplinary organizations) and the schooling tradition. Classic authors like Max Weber (WEBER, 2003) and Erving Goffman (GOFFMAN, 1968) refer to ideal types - relating to specific character of each sector - the combat for militarized sectors, the teaching activity for the school systems, competition and focus on profit by the market, among others. Nonetheless, that viewpoint logic is not in line with the occurrences of society daily life. Logic shaping and transforming historicity is somewhat more chaotic.

Thus, it is not surprising that great political crisis, such as the one in Brazil in June 2013, or French one in 1968, corresponds necessarily to multi-sector mobilizations, located simultaneously in several different spheres, autonomous from each other. This is what constitutes the main structural (BOURDIEU, 1980) factor for the comprehension of social crisis. From here comes the observation of increased mobility, where chaotic social aspects lead to a high level of fluidity of the political sphere.

\section{CRISIS ROOTS AND THE LOSS OF LEGITIMACY}

All crises are in a certain way a legitimacy crisis. They relate to loss of assets occurring in contexts of political fluidity. Accordingly, as an asset, legitimacy can be obtained by the accumulation of a high level of diffuse support (EASTON, 1979; CASTRO, 2017). Namely, goodwill on behalf of members of a political system. either by calling upon symbols of common interest, or by strengthening the degree of recognition of members of a given political community.

Thus, a process of political legitimacy loss is seen as the reduction of diffuse social support, a process that can take place in various ways. First, the expectation of members of a national political system cannot be met over a long period of time. 
Second, the loss of legitimacy can be seen in the resurgence of a gap between the values inculcated to the individuals during their socialization, and the overall operation of the political system, the representation of official institutions, or the behavior and the perspectives expressed by authorities.

Loss of legitimacy of political systems is a phenomenon which operates in the long term. Thus, a diffuse support stands longer than a specific - seen as tactical one Therefore, loss of legitimacy constitutes a critical aspect in the formation of a political crisis, and the level of diffuse support plays the most important part. However, a reservoir of diffuse support permits an extension of time for a given political regime.

\section{FINDING WAYS OUT: THE INSTITUTIONAL HYPOTHESIS}

Although paradoxical, a potential solution for political crisis passes through institutionalized channels. That means that political confrontations tend to be channeled towards certain institutional sectors of the legitimate political spectrum. As shown in 2011 with 15-M (acronym for May), the Spanish antiausterity movement that in the beginning 2014 led to the creation of "Podemos", a new political party to run the national elections (RAMIRO; GOMEZ, 2016). Or, as stated by Michel Dobry, that was the case in France in 1968 with the dissolution of the National Assembly. In both situations, the implementation or the activation of standard regulation was visibly followed by a normalization of the political confrontation, even if followed by less intense waves of political demonstrations.

Thereby, it may be necessary to consider the bargaining which is carried out between the various players, and finally the negotiated character of the events, as it was the case in the examples previously quoted. And that corresponds to a de facto anticipation, for it coincides with the emergence of a new political formation in Spain, or as in France with Parliament dissolution and the transfer of power to the opposition party. Accordingly, those calculations guarantee that the diverse social players present in the political scene do not lose too many assets. This is definitely a political approach which legitimates (and self-regulates) faster shifts towards a specific political direction.

Consequently, political action gets lower possibilities to attain scale. However, this is a consistent characteristic of negotiations between legitimate players in the political sphere, as shown by scholars on crisis processes in democratic systems (STREEK, 2011; VALENZUELA, 1978). 
A third strategy to overcome a political crisis is through a player with charismatic traits (WEBER, 2003). This happens when an individual, who has a kind of "certificate of personal qualifications" in the public opinion, offers an outcome, a conclusion where he can intervene (CHAMPAGNE, 1990; CASTRO, 2019). Therefore, players with these characteristics can influence the political world and provoke various confronting segments to take a position. However, these charismatic strategies constitute a distinct kind of outcome emerging from confrontations, which may lead to success or failure in attaining power.

\section{CONCLUSION}

Finally, we will call fluid political periods, the specific class of critical situations which correspond to transformations in a state of a complex system, when they are followed by multi-sector mobilizations. Such fluid situations are specific to a social dynamic and a tactical game that are structurally original. That is, one which cannot be reduced to the binary logic of common sense: the opposition to the status quo and political stability on one hand, and social disintegration and rule of violence on the other hand.

It's worth repeating that a methodological simplification can compromise a broader view of the natural complexity of social processes. A comprehensive perspective, far from constituting an obstacle to the intelligibility of these processes, represents one of their essential conditions.

Further comments can be made. Initially, it is when an official sector is experiencing a transition in power that a social player can understand its strategic role. Therefore, we conclude that an individual is neither more nor less rational in political contexts of fluidity or in stability. In addition, from the Marxist theory of social conflict, there is, in different ways, the survival of social forms from the past which appears in the heart of social upheavals (DUPRAT, 1973). And these "roles" coming from the past are different variables with a potential to influence the outcomes of a situation of political fluidity (SOUZA; JODKHA; REHBEIN, 2017).

The main debate in this paper was to show that one has to understand the political actions of participants in such processes as rooted in a very clear and logic rationality: their own political group rationality, based on the stock of knowledge they possess in a given time 
If one agrees that a political resource is not a form of social capital which can be automatically transferred to specifics actors, then, institutions cannot be understood as perfectly logical, but as structures enclosing different levels of uncertainty. In addition, it is necessary to understand that political crises are sometimes the result of processes of deterioration in a given state of a specific social system. In this sense, an analysis should stop trying to find the origins of a crisis, aiming at unveiling causality, and categorizing those crises in categories developed ex ante. Furthermore, an analysis should not look solely into the outcomes of crises. As stated above, the internal complexity of a political process is more significant for analytical purposes. This is because, with this perspective, one can clarify the social, political and institutional moves with the necessary material for social scientists to deliver to the main players in the political scenario. It is also the kind of material that is more valuable to be returned to society as a whole, with its interpretation on the stated historical phenomena.

\section{REFERENCES}

BOURDIEU, P. Le sens pratique. Paris: Éditions de Minuit, 1980.

CASTELLS, M. Networks of outrage and hope: social movements in the internet age. London: Polity Press, 2015.

CASTRO, C. P. Linking poverty and the environment: participatory communitybased approaches, games of imperfect information and the Convention on Biological Diversity. Meridiano 47 - Journal of Global Studies, Brasília, v. 18, p. 1-15, maio, 2017. Available at: http://periodicos.unb.br/index.php/MED/ article/view/5292. Viewed on: 12 may 2017.

CASTRO, C. P. La presse et le symbolisme de l'Amazonie en Europe à la fin du XXème siècle. Paris: Librinova, 2019.

CHAMPAGNE, P. Faire l'opinion. Le nouveau jeu politique. Paris: Éditions de Minuit, 1990.

CHAZEL, F. La mobilization politique, problémes e dimensions. Revue Française de Sciences Politiques, Paris, n. 25, p. 502-516, june, 1975.

DEUTSCH, K. W. Social mobilization and political development. The American Political Science Review, Londres, v. 55, n. 3, p. 493-514, sept. 1961.

DOBRY, M. Mobilisations multisectorielles et dynamiques des crises politiques. Revue Française de Sociologie, Paris, n. 24, p. 395-419, july./sept. 1983. 
DOBRY, M. Sociologie des crises politiques. Paris: Presses de la Fondations Nationale de Science Politiques, 1992. 319 p. (Coll. Références, 29).

DRAKE, P. W. Labor movements and dictatorships. The Southern Cone in comparative perspective. Baltimore and London: The John Hopkins University Press, 1996.

DUPRAT, G. Marx, Proudhon: théorie du conflit social. Paris: Éditions Ophrys, 1973. 176 p. (Coll. Cahiers de l'Institut d'Études Politiques de Strasbourg).

EASTON, D. A system analysis of political life. Chicago and London: Chicago University Press, 1979.

GOFFMAN, E. Asiles: étude sur la condition sociale des malades mentaux et autres reclus. Paris: Editions de Minuit, 1968. 447 p. (Coll. Le sens commun).

McADAM, D.; TARROW, S.; TILLY, C. Toward an integrated perspective on social movements and revolution. In: LICHBACH, M. I.; ZUCKERMAN, A. (eds.). Comparative politics. Rationality, culture and structure. Cambridge, New York and Melbourne: Cambridge University Press, 1997. p. 142-173.

NOGUEIRA, J.; CASTRO, C. P. Internet, democracy and governmental communications: content analysis of the presidency of the republic portal Brasil. Facebook Page. Revista de Estudos da Comunicação, Curitiba, v. 15, n. 37, p. 134-151, jan./mar. 2014.

RAMIRO, L.; GOMEZ, R. Radical-left populism during the Great Recession: Podemos and its competition with the established radical left. Political Studies, Londres, v. 65, n. 15, p. 108-126, june 2016.

SOUZA, J., JODKHA, S.; REHBEIN, B. Inequality in capitalist societies. London: Routledge, 2017.

STREEK, W. The crises of democratic capitalism. New Left Review, n. 71, Sept./Oct. 2011.

VALENZUELA, A. Chile. In: LINZ, J.; STEPAN, A. (eds.). The breakdown of democratic regimes. Baltimore: The John Hopkins University Press, 1978. p. $648-672$

WEBER, M. Economie et société. Paris: Pocket, 2003. 633 p. 
